\title{
A review on home yard medicinal plants commonly used in diabetic treatment
}

\begin{abstract}
Bangladesh is a land of tropical forests and boggy jungle. As boasted with floral genetically plantation of herbs made it an excellent source of medicinal plants. The modern analysis of herbal plants designed with highly esteemed source of medicine to treat Diabetes mellitus. On these consequences the researcher illustrated the local application of raw medicinal products of herbs as a remedy of controlling diabetes. Herbal practitioner in Bangladesh both registered and nonregistered traditionally use some of the herbal plants and active chemical constituents which have a role in the management of Diabetes including type 1 and type 2. The research protocols is subjected as local implementation of home yard medicinal plant to control diabetes in a minimal cost reviewing for its anti diabetic activity without side effects.
\end{abstract}

Keywords: amyline antagonism, cAMP, diabetes mellitus, insulinotropic, phytomedicine, herbal practitioner
Volume 8 Issue 6 - 2018

\author{
Avra Pratim Chowdhury,' Nibedita \\ Thakuria, ${ }^{2}$ ShaikhBokhtear Uddin, ${ }^{3}$ Raja \\ Chakraborty ${ }^{4}$ \\ 'Department of Microbiology,Assam down town University, \\ India \\ ${ }^{2}$ Department of Microbiology, Assam down town University, \\ India \\ ${ }^{3}$ Department of Botany, University of Chittagong, Bangladesh \\ ${ }^{4}$ Department of Pharmacy, Assam downtown University, India
}

Correspondence: Avra Pratim Chowdhury, M Phil. researcher, Department of Microbiology, Assam down town University, India, Email avrenu132@gmail.com

Received: October 27, 2018| Published: December 06, 2018

\section{Introduction}

Bangladesh created own environmental support for tree plantation due to its monsoon effects. The concern of isolation and identification of phytomedicinal plants based on tropical rain forest area in Bangladesh is subjected on these global effects. For this reason, the research work has been carried out at Chittagong metropolitan and rural based area in Bangladesh. Here the reviewers tried to follow up differentiate implementation of raw herbal products for the treatment of Diabetic patient collected from home yard ground. Inexpensive and easily accessible nature of the traditional medicines made it an integral part of public health services in Bangladesh. Diabetes mellitus is metabolic diseases characterized in group of patterns incorporate with high blood sugar (glucose) levels that result from insufficient insulin secretion. ${ }^{1}$ Phyto medicines have been highly esteemed source are widely used today indicating that herbs usually inconsideration growing part of modern Bio tech application. ${ }^{2}$ Home yard herbal plants with active chemical constituents play a vital role in the treatment of Diabetes mellitus type 1 and type 2 maintaining blood sugar level in normal 70 to 100 , or less than $140 \mathrm{mg} / 100 \mathrm{ml} .^{3,4}$ The Ayurvedic village prescribers were compiled along with their specific treatment and authentic suggestion as use this raw medicine discussed in this review.

The herbal practitioner suggested comfortless and effective ways to practice medicine for diabetic treatment depending on home yard source. ${ }^{5}$ Natural home yard plants, crops, seeds, leaves considered as performing potent candidates with pharmaceutical synthetic oral medicines. ${ }^{6}$ So steps should be taken from root label to optimize a procedure for ant diabetic screening of different plant extracts isolating new bioactive compounds for the discovery of home yard available herbal anti diabetic drugs. ${ }^{7}$ Herbal village practitioner chose Fenugreek (Trigonellafoenum-graecum L., family Leguminasae) seeds due to its active components 4-HI (4-hydroxyisoleucine), this potential active compound is applied on diabetic patient in a successive patterns. Another available source of application is chosen by the ayurvedic doctors Neem (Azadirachtaindica, mahogany family). ${ }^{8}$ The present study evaluated the long term hypoglycemic effect of Black cumin (Nigella sativa) holy basil (Ocimum sanctum), Cherotha (Swertiachirayita), Seeds of Mehogone (Swieteniamacrophylla), Bitter gourd (Momordicacharantia L.) to treat as yard plenty ailments based on activities regarding anti diabetic application. The in vitro application of aqueous extract of aloevera (Aloe barbadensis) leaves examined for its anti diabetic activities against alloxan induced diabetic mice. But aloevera maintains a long term hypoglycemic effect accordance with observational studies of village herbal practitioner, 9,10 proved the basic fundamentals need of diabetic patient. ${ }^{11}$

Isolation and Identification of home yard anti diabetic plants:

\begin{tabular}{lll}
\hline Plants name & Scientific identity & Active initiator compounds \\
\hline Aloe vera & Aloe barbadensis & Methylenecycloartanol. \\
Garlic & Allium sativum & Diallyldisulphide oxide(allicin) \\
Onion & Allium cepa & Mehtyl cysteinesulphoxide \\
Neem & Azadirachtaindica & Oleic\& stearic acids. (50\%, 20\%) \\
Noyontara & Catharanthus roseus & Vinculin alkaloids \\
Telacucha & Capparisdeciduas & Phenyl propanoid, thymol (24.4\%) \\
\hline
\end{tabular}


Table continued..

\begin{tabular}{lll}
\hline Plants name & Scientific identity & Active initiator compounds \\
\hline Bitter gouard & Momordicacharantia & Glycosides momordin, charantosides,charantin. \\
Holy basil & Ocimum sanctum & Eugenol 4,5,Cinnamyl acetate 5 and Beta-elemene 5. \\
Cherotha & Swertiachirayita & Ophelic acid \\
Black berry & Syzygiumcumini & Kaempferol-3-O- $\beta$-D glucuronopyranoside \\
Seeds of Mehogony & Swieteniamacrophylla & Limonoids \\
Fenugreek & Trigonellafoenumgraecum & Trogonelline, and Coumarin \\
\hline
\end{tabular}

\section{Methodology}

\section{Collection of authentication}

The plant used in this study was collected from the stand at the courtyard around the Dean's Office, Botanical garden, Home yard garden of ayurvedic doctor and Faculty of Biological Sciences, University of Chittagong. The specimens were authenticated by Dr. Shaikh Bokhtear Uddin, a botanist in the Department of Botany,
University of Chittagong

\section{Field survey}

A total of twenty Herbal practitioners have been interviewed. They have age group between 35-50. In this contrary approaching honored by at least 10 to $25 y$ years experience. So following nine practitioners were selected for their logical arguments and also for effective prescriber.
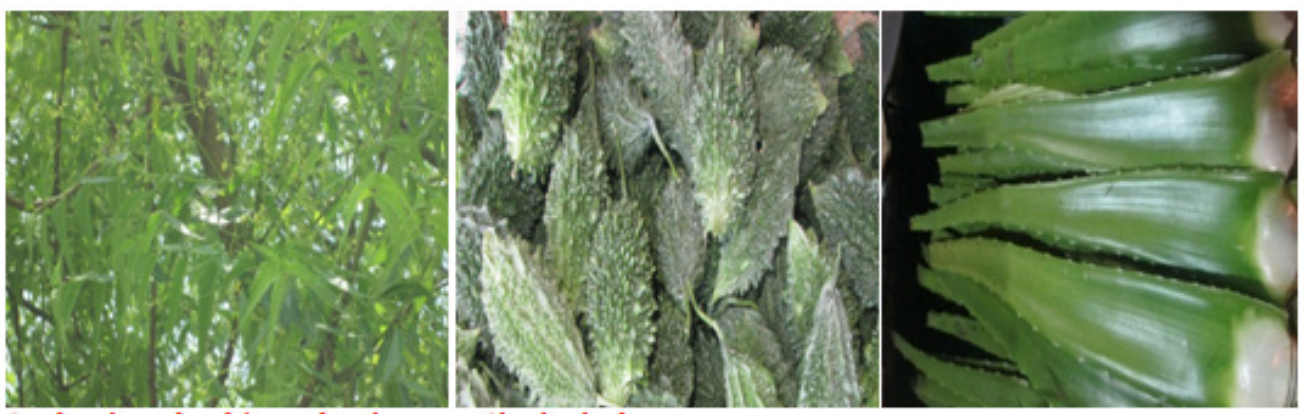

Azadirachtaindica Momordicacharantia Aloe barbadensis
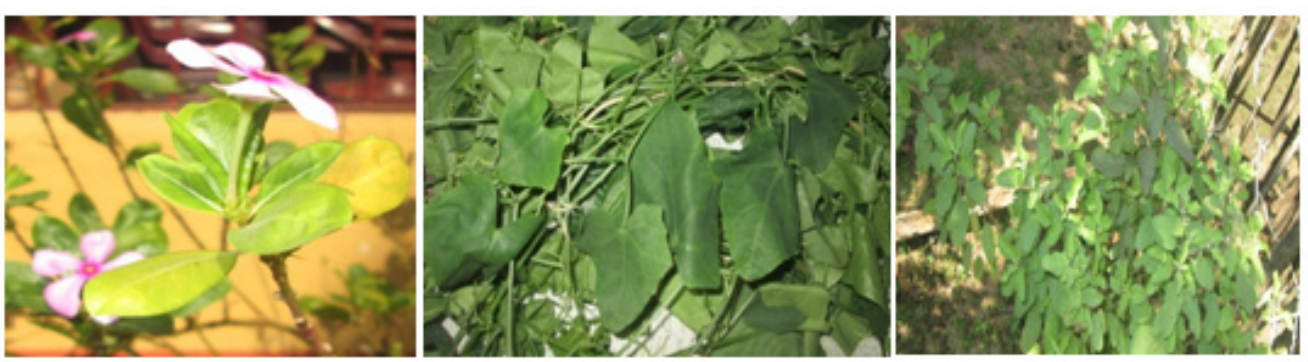

Catharanthus roseus Capparisdeciduas Ocimum sanctum
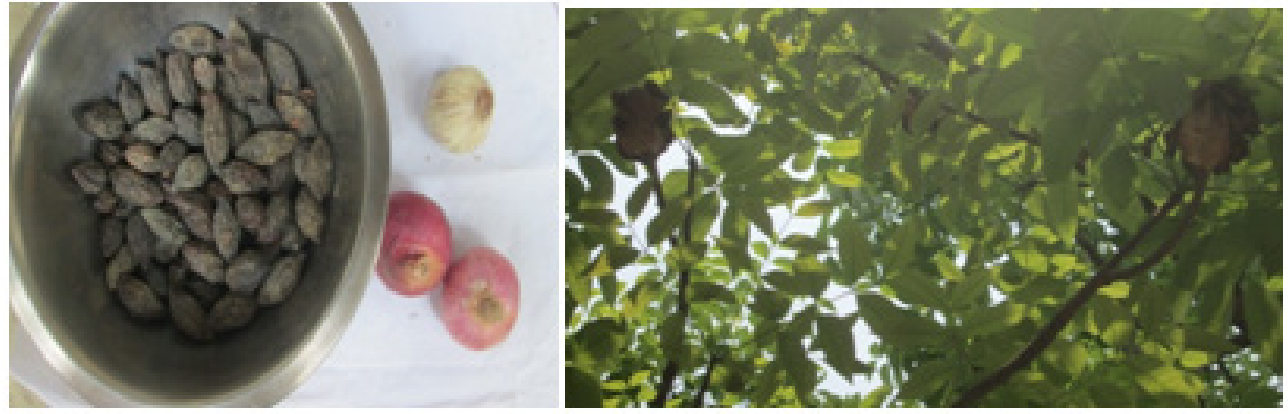

Terminaliachebula, Allium cepa, Allium sativum. Swieteniamacrophylla 


\section{Preparation of anti diabetic suspension}

Saturate solution of Neem leaves (over night): $250 \mathrm{ml}$

Fenugreek: 20gm

Alovera gel: 10gm

Seeds of Mehogone: $5 \mathrm{gm}$

\section{Results}

Natural resources considered as potent candidates for drug discovery and are playing a pivotal role in drug development programs. Moreover, many medicinal herbs provide a rich mine for bioactive chemicals that are markedly free from undesirable side effects and of powerful pharmacological actions. ${ }^{12-14}$

\section{Discussion}

Twenty Herbal practitioners have been interviewed remedies the herbs as medicine. They have age group between 35-50. In this contrary approaching honored to them by at least 10 to 25years experience. So following nine practitioners (Table 1) were selected for their logical arguments as for effective prescriber. A total of 17 species have been found to be used for the treatment of diabetes in 16 /genera under six Families and subjected to Herb, shrub, tree and climber. From the analysis of herbal formularies, it has been observed that the percentage of use of plant parts contain $37 \%$ leaves, $17 \%$ entire plant, $16 \%$ seed, $14 \%$ Fruit, $6 \%$ Flower, $4 \%$ Bulb, 6\% Bark (Figure 1). Than the researcher and associates selected twelve home yard phytomedicinal plants and their remedies upon patient for three months (Table 2). The ayurvedic village doctor practices their home made medicines where as their patient became cure from their outdoor suggestion (Figure 2).

The research survey continued with daily assessment of history in diabetic and non diabetic patients being with administered specific isolated plant medicine by respective doctor. Medicinal plants that have been shown to improve the diabetic state without apparent enhancement of insulin secretion tested for effective constituents of raw alkaloids properties suggested by Ayurvedic village doctors (Figure 3 \& Figure 4). The constituents and active properties regarding hypoglycemic effect and antibiotic sensitivity has been studied and observed by researcher from several blood reports of patients in a collective profile (Table 3). From this group study and research survey, the outcomes resulted about self home remedies for diabetic patient in regular practice at a minimal cost. Garlic, onion and fenugreek $(48.57 \%, 60 \%$ and $76.73 \%$ curability rate) is very much effective to maintain hypoglycemic level in both diabetic and non diabetic patients. Blackberry, hollybasil and aloevera cultivation is the good source for home yard cultivation due to antibiotic and antidiabetic effects on patients without having any discomfort for its own chemical components. These include eugenol, linalool, estragole, limonene, citral, methylchavicol, and methyl cinnamate. The more distinctly scented varieties boast a predominant volatile compound that out-competes the rest, producing a characteristic aroma.

Momordin, Ophelic acid and Stearic acid produced acidity in stomach accelerating the receptor of hydrogen antagonistic to probiotic production. Indigestion may result if generic Compound is administered in fasting condition of patient. So the raw juice of Neem (58.93\%curability rate) leaves, Cherotha and Bitter gourd (56.44\% curability rate) should be suggested in $200 \mathrm{ml}$ daily considerable in age 35-55. This medicine should not be prescribed to complete insulin dependent patient. So the curability rate comes out as best suggestive for Bitter gourd for type 1 and Cherotha is suggestive for type 2. But as regular practice to control sugar label as preventive medicine, Cherotha (75.11\%curability rate) is the best selection for practitioner. Telakucha and Noyontara is less effective than others and it may also cause ulceration to intestine of immune suppressed patient. So the ayurvedic practitioners suggest as observing the history and blood report of diabetic patients. The graphical presentation Figure 5-8 showed the diagrammatic points of view that already been described in noted discussion.

Table I Herbal Practitioners and their prescribed remedies of diabetic patient

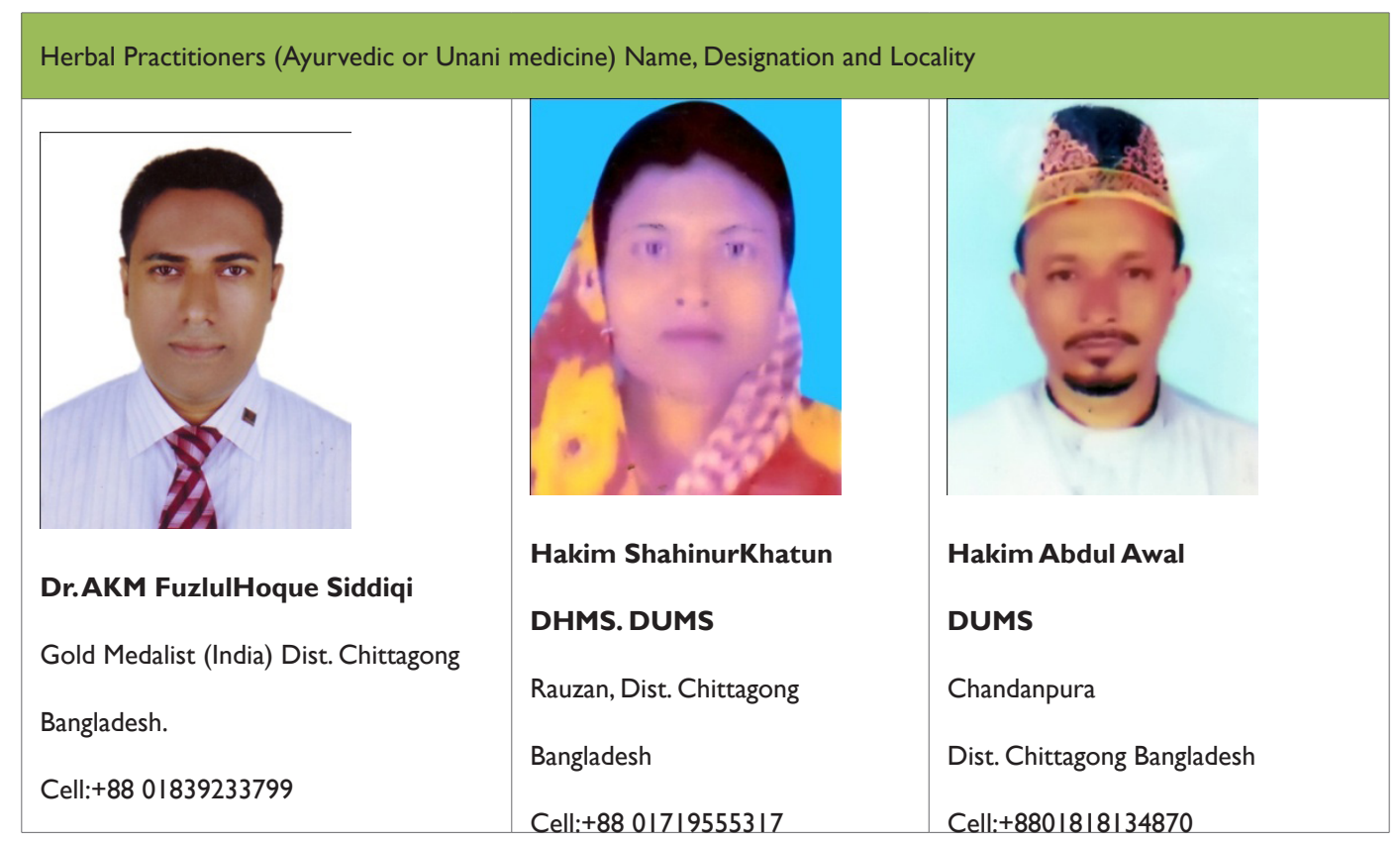




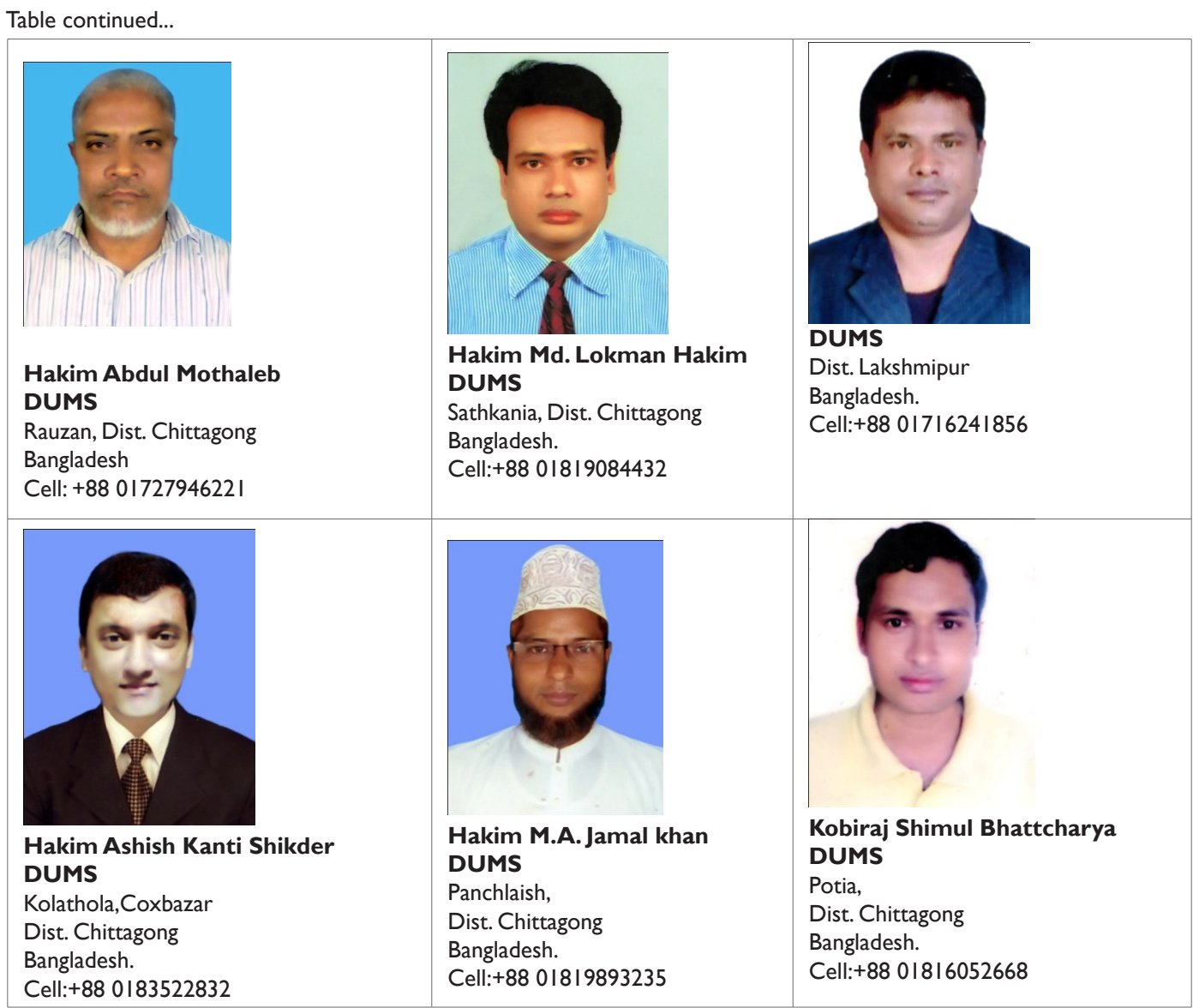

Table 2 Herbal prescribed remedies and its mode of application

\begin{tabular}{|c|c|c|c|}
\hline Plants Used. & Mode of application & & \\
\hline Aloe barbadensis (Aloe vera), & Leaves & Grinding in juice and used as syrup. & Once daily up to one year. \\
\hline Allium cepa: (onion) & Root crops, Bulbs, stem, tops. & Grinding in juice and used as pulpy syrup. & Two times daily up to one year \\
\hline Allium sativum: (garlic) & Root crops Bulbs, stem, tops & Grinding in juice and used as pulpy syrup. & Two times daily up to one year. \\
\hline Azadirachtaindica: (Neem), & Leaves, Flowers & Grinding in juice and used as syrup. & Once daily up to one year. \\
\hline $\begin{array}{l}\text { Catharanthus roseus } \\
\text { (Noyontara) }\end{array}$ & Flowers & Grinding in juice and used as syrup. & Once daily up to six months \\
\hline Capparisdeciduas (Telakucha), & Leaves & Grinding in juice then boiled and used as syrup & Two times daily up to one year. \\
\hline $\begin{array}{l}\text { Swieteniamacrophylla ( Seeds } \\
\text { of Mehogone), }\end{array}$ & Seed & Dried and grinding form to use as powder. & Once daily up to six months \\
\hline $\begin{array}{l}\text { Momordicacharantia: (bitter } \\
\text { gourd) }\end{array}$ & Fruit & Grinding pulp and its juice. & Once daily up to one year. \\
\hline Ocimum sanctum: (holy basil) & Leaves & Grinding in juice and used as syrup. & Once daily up to six months \\
\hline Swertiachirayita(Cherotha) & Stem and Bark & Dried and wet. & Once daily up to six months \\
\hline $\begin{array}{l}\text { Trigonellafoenumgraecum: } \\
\text { (fenugreek) }\end{array}$ & Seed & Dried and grinding form to use as powder & Once daily up to one year. \\
\hline Syzygiumcumini: (Black berry) & Fruit & Dried and grinding form to use as powder & Once daily up to one year. \\
\hline
\end{tabular}


Table 3 Synchronized percentages in curability of diabetic patient

\begin{tabular}{|c|c|c|c|c|}
\hline \multirow[t]{2}{*}{ Plants name } & \multirow[t]{2}{*}{ Mode of action } & \multicolumn{2}{|c|}{$\begin{array}{l}\text { History of curability }(\%) \\
\text { according to patient registry, } \\
\text { December-February (20 I 5- } \\
20 \text { I6) }\end{array}$} & \multirow[t]{2}{*}{$\begin{array}{l}\text { Result } \\
\text { (According } \\
\text { to patient } \\
\text { registry) }\end{array}$} \\
\hline & & Type I & Type 2 & \\
\hline Aloe barbadensis (Aloevera) & $\begin{array}{l}\text { As medicine, it is used and suggested to the patient } \\
\text { in syrup suspension of Aloevera for } 4 \text { - I } 4 \text { weeks. } \\
\text { The outcome is resulted significant by hypoglycemic } \\
\text { effect both clinically and experimentally. Scientifically } \\
\text { it is proved Aloevera gel is used in reducing sugar in } \\
\text { diabetes under studying prescription of Ayurvedic } \\
\text { village doctors. }\end{array}$ & $\begin{array}{l}\text { Total no. } 40 \text {, } \\
\text { Cure: } 26, \\
65 \%\end{array}$ & $\begin{array}{l}\text { Total no. } 12 \\
\text { Cure: } 7 \\
58.33 \%\end{array}$ & $61.67 \%$ \\
\hline Allium sativum (garlic) & $\begin{array}{l}2.4 \mathrm{gm} \text { garlic tablet is administered for patient } \\
\text { containing } 31.2 \mathrm{mg} \text { allicin in high dose. The actual dose } \\
\text { is used to control and regulate hyperglycemic effect } \\
\text { after } 5 \mathrm{~h} \text { of administration. }\end{array}$ & $\begin{array}{l}\text { Total no. } 25 \\
\text { Cure: } 10 \\
40 \%\end{array}$ & $\begin{array}{l}\text { Total no. } 14 \\
\text { Cure: } 8 \\
57.14 \%\end{array}$ & $48.57 \%$ \\
\hline Allium cepa (onion) & $\begin{array}{l}\text { The control of hyperglycemic effects regarding } \\
\text { the systemic routine studies showed that oral } \\
\text { administration of the ethanol extract of onion } \\
\text { regulated the blood-sugar level, normalizing the activity } \\
\text { of both liver hexokinase and glucose-6- phosphatase. }\end{array}$ & $\begin{array}{l}\text { Total no. } 10 \\
\text { Cure: } 7 \\
70 \%\end{array}$ & $\begin{array}{l}\text { Total no. } 8 \\
\text { Cure: } 4 \\
50 \%\end{array}$ & $60 \%$ \\
\hline Azadirachtaindica(Neem) & $\begin{array}{l}\text { The ingradients suggested by doctors followed in } \\
\text { suppressing digestion and absorption at intestinal } \\
\text { and hepatic cells. The raw contents prepared } \\
\text { homemade medicine is used to decrease of } \\
\text { carbohydrate. This suggestion includes with no risk of } \\
\text { hypoglycemia,hyperinsulineia and undesirable weight } \\
\text { gain.But carries hyper risk of stomach ache. }\end{array}$ & $\begin{array}{l}\text { Total no. } 56 \\
\text { Cure: } 38 \\
67.86 \%\end{array}$ & $\begin{array}{l}\text { Total no. } 44 \\
\text { Cure: } 22 \\
50 \%\end{array}$ & $58.93 \%$ \\
\hline Capparisdeciduas (Telakucha), & $\begin{array}{l}\text { Village Ayurvedic doctors suggest the raw juice of } \\
\text { telakucha. The activity for } \alpha \text {-glucosidase was assessed } \\
\text { according to the method of enzyme inhibition directly. } \\
\text { Patients were administered pasted juice for three } \\
\text { weeks, and the outcomes were fruitful from patient } \\
\text { registry. }\end{array}$ & $\begin{array}{l}\text { Total no. } 9 \\
\text { Cure: } 6 \\
66.67 \%\end{array}$ & $\begin{array}{l}\text { Total no. } 4 \\
\text { Cure: I } \\
25 \%\end{array}$ & $45.84 \%$ \\
\hline $\begin{array}{l}\text { Catharanthus } \\
\text { roseus(Noyontara) }\end{array}$ & $\begin{array}{l}\text { The active compound vinculin alkaloids decrease } \\
\text { the hyperglycemic levels by increasing anti cytotoxic } \\
\text { factors in liver. }\end{array}$ & $\begin{array}{l}\text { Total no. } 39 \\
\text { Cure: } 23 \\
58.97 \%\end{array}$ & $\begin{array}{l}\text { Total no. } 13 \\
\text { Cure: } 9 \\
69.23 \%\end{array}$ & $64.10 \%$ \\
\hline $\begin{array}{l}\text { Momordicacharantia } \\
\text { (Bitter gourd) }\end{array}$ & $\begin{array}{l}\text { It is widely used and administered to type I diabetic } \\
\text { patient suffering from obesity. The hypolipidemic and } \\
\text { hypoglycemic effects comes out by synthesis of active } \\
\text { compound momordin and cucurbitacin B.The potential } \\
\text { rate of medicinal extract is highly potent on the field } \\
\text { basis application. }\end{array}$ & $\begin{array}{l}\text { Total no. } 65 \\
\text { Cure: } 46 \\
70.77 \%\end{array}$ & $\begin{array}{l}\text { Total no. } 38 \\
\text { Cure: } 16 \\
42.10 \%\end{array}$ & $56.44 \%$ \\
\hline $\begin{array}{l}\text { Swieteniamacrophylla } \\
\text { ( Seeds of Mehogone) }\end{array}$ & $\begin{array}{l}\text { Seeds of extracted medicine in oral glucose tolerance } \\
\text { test (OGTT) is administered for exhibiting ( } 60 \% \\
\text { reduction) in blood glucose level. The outcomes of } \\
\text { treated patient resulting after } 12 \text { consecutive days of } \\
\text { oral treatment ( } 300 \mathrm{mg} / \mathrm{kg}) \text {. It is also potent antibiotic } \\
\text { active compound against gangrenous bacteria. }\end{array}$ & $\begin{array}{l}\text { Total no. } 19 \\
\text { Cure: } 12 \\
63.16 \%\end{array}$ & $\begin{array}{l}\text { Total no. } 10 \\
\text { Cure: } 6 \\
60 \%\end{array}$ & $61.58 \%$ \\
\hline $\begin{array}{l}\text { Ocimum sanctum: } \\
\text { (holy basil) }\end{array}$ & $\begin{array}{l}\text { Leaves of holy basil produced alcohol extract. In } \\
\text { ayurvedic treatment pasted syrup was administered } \\
\text { orally which significantly reduced glycemia and } \\
\text { enhanced exogenous insulin action. }\end{array}$ & $\begin{array}{l}\text { Total no. } 70 \\
\text { Cure: } 46 \\
65.71 \%\end{array}$ & $\begin{array}{l}\text { Total no. } 85 \\
\text { Cure: } 66 \\
77.65 \%\end{array}$ & $71.68 \%$ \\
\hline
\end{tabular}


Table continued...

\begin{tabular}{|c|c|c|c|c|}
\hline \multirow[t]{2}{*}{ Plants name } & \multirow[t]{2}{*}{ Mode of action } & \multicolumn{2}{|c|}{$\begin{array}{l}\text { History of curability }(\%) \\
\text { according to patient registry, } \\
\text { December-February (20 I5- } \\
2016)\end{array}$} & \multirow[t]{2}{*}{$\begin{array}{l}\text { Result } \\
\text { (According } \\
\text { to patient } \\
\text { registry) }\end{array}$} \\
\hline & & Type I & Type 2 & \\
\hline Swertiachirayita (Cherotha) & $\begin{array}{l}\text { The insulin levels are maintained on the treatment of } \\
200 \mathrm{mg} / \mathrm{kg} \text { from extracted ethanols. The treatment of } \\
\text { diabetic patient was compared to the diabetic control } \\
\text { from abnormal glucose homeostasis. The result was } \\
\text { subjected to leading part on type I diabetes due to } \\
\text { selective and progressive destruction of pancreatic } \\
\beta \text {-cells was about to cure. }\end{array}$ & $\begin{array}{l}\text { Total no. } 122 \\
\text { Cure: } 86 \\
70.49 \%\end{array}$ & $\begin{array}{l}\text { Total no. } 74 \\
\text { Cure: } 59 \\
79.73 \%\end{array}$ & $75.11 \%$ \\
\hline $\begin{array}{l}\text { Syzygiumcumini: } \\
\text { (Black berry) }\end{array}$ & $\begin{array}{l}\text { The juice and pasted seed and leaves extract are the } \\
\text { medicinal source of hydrolyzed tannins. This compound } \\
\text { is the active source of transforming growth factor } \\
\text { beta I, Fibrinoactin and growth factor of connective } \\
\text { tissue in pancreatic islets. It contains Plasminogen } \\
\text { activator which inhibits the active site of renal cortex } \\
\text { in type } 2 \text { diabetic patient. }\end{array}$ & $\begin{array}{l}\text { Total no. I5 } \\
\text { Cure: I I } \\
73.33 \%\end{array}$ & $\begin{array}{l}\text { Total no. } 8 \\
\text { Cure: } 6 \\
75 \%\end{array}$ & $74.17 \%$ \\
\hline $\begin{array}{l}\text { Trigonellafoenumgraecum: } \\
\text { (fenugreek) }\end{array}$ & $\begin{array}{l}\text { The fenugreek is a complete diet for regular } \\
\text { practices of diabetic or non diabetic patient. Studying } \\
\text { consecutive patient history the result of fenugreek } \\
\text { significantly awesome to reduce fasting blood sugar. } \\
\text { The case study was improved glucose tolerance test in } \\
\text { type } 2 \text { after urine analysis. }\end{array}$ & $\begin{array}{l}\text { Total no. } 106 \\
\text { Cure: } 92 \\
86.79 \%\end{array}$ & $\begin{array}{l}\text { Total no. } 48 \\
\text { Cure: } 32 \\
66.67 \%\end{array}$ & $76.73 \%$ \\
\hline
\end{tabular}

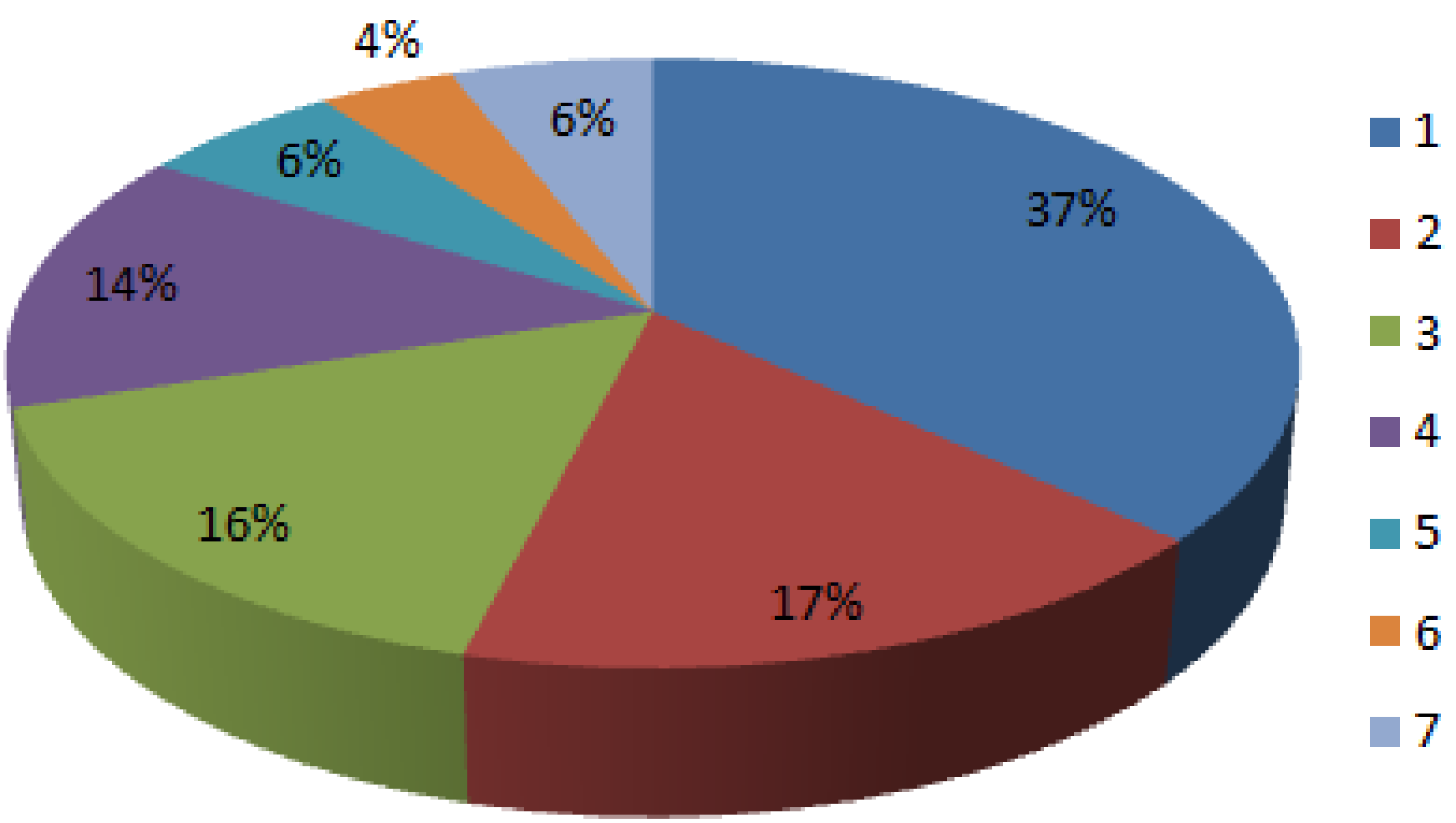

Figure I Analysis of remedies obtained from different plant parts for Diabetes Mellitus I. L - Leaves, 2. EP - Entire plant, 3. S - Seed, 4. F - Fruit, 5. FL - Flower 6.B - Bulb, 7. BR - Bark. 

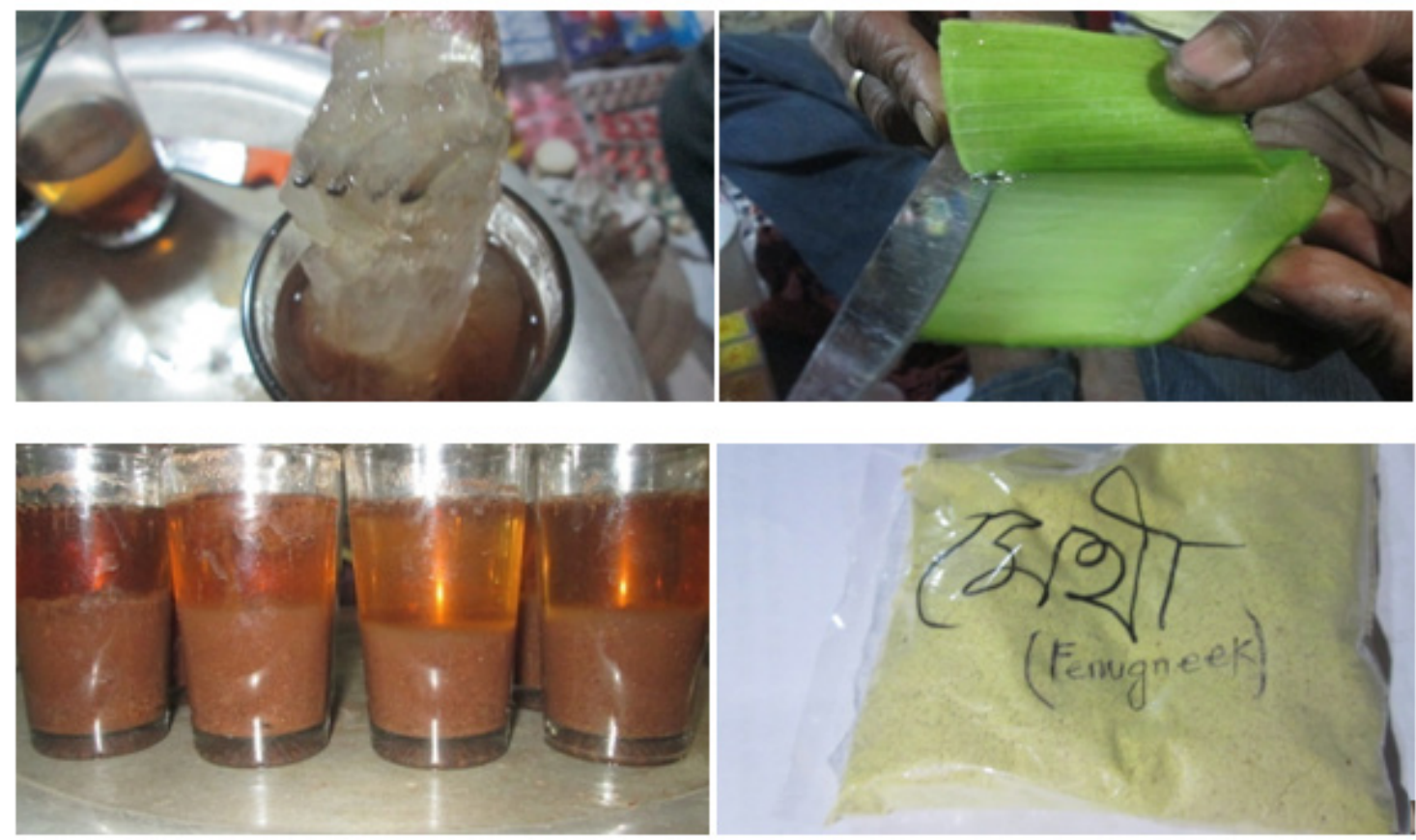

Figure 2 Preparation of Anti Diabetic Suspension by Ayurbedic village doctor Md. Najmul Hasan.
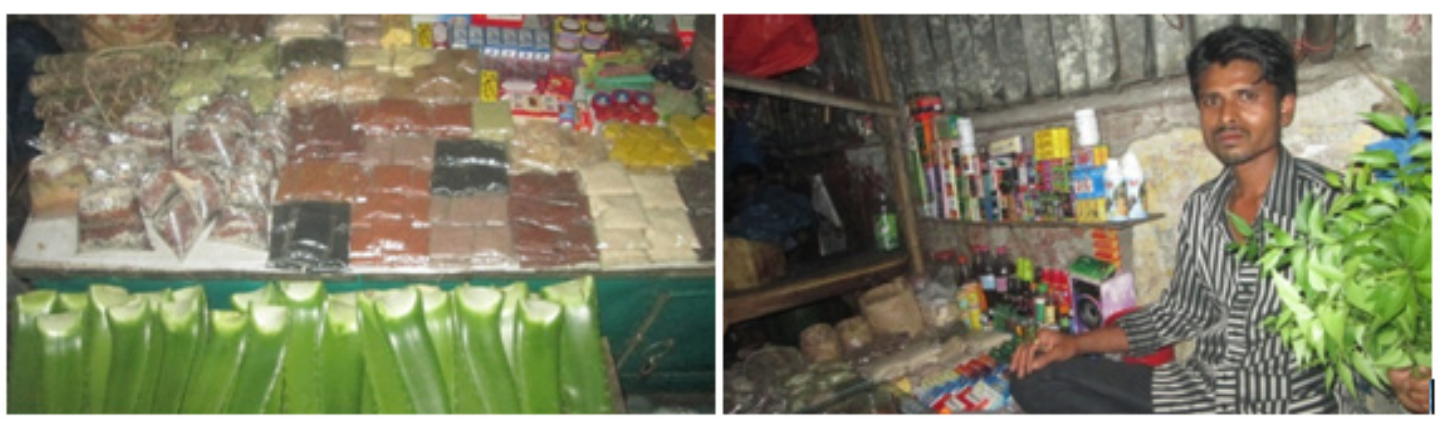

Figure 3 Ayurbedic village doctor Md. Najmul Hasan showed home yard medicinal plants, and home made medicinal ingredients from leaves, bark, fruits and roots.
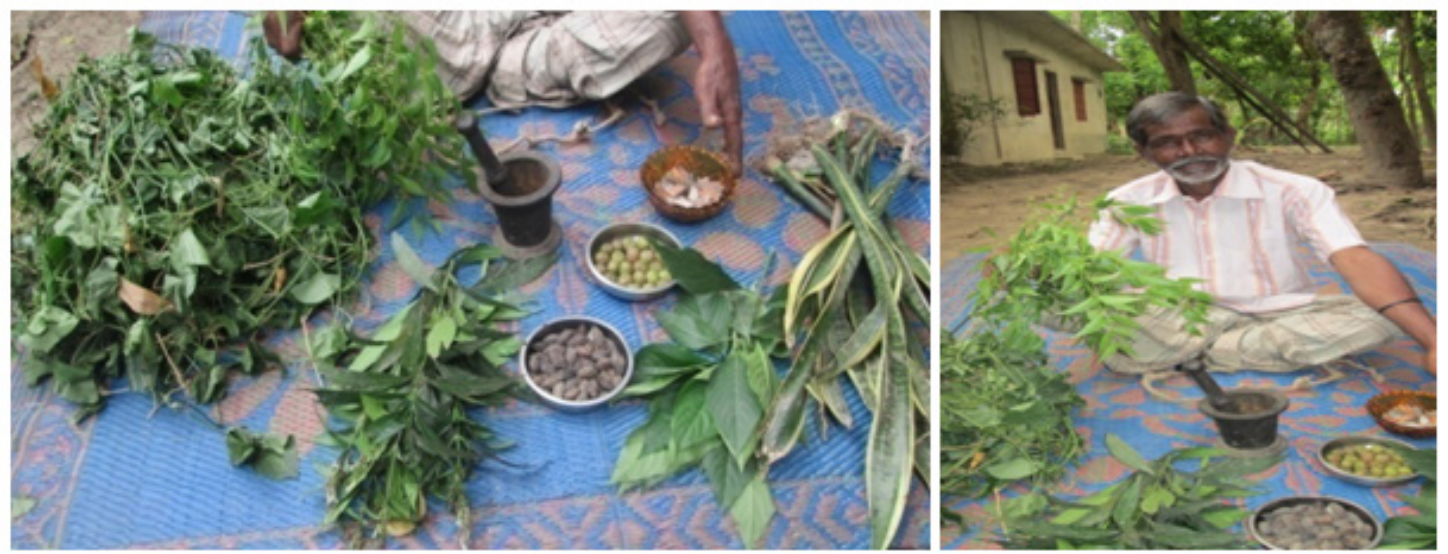

Figure 4 Ayurvedic village doctor Mr. Ghandhi Das showed home yard medicinal plants and its fruits with roots. 
1.Alovera, 2.Garlic, 3.Onion ,4.Neem,5.Telakucha 6.Noyontara, 7.Bittergourd, 8.Seeds of Mehogony, 9.Holy basil, 10.Cherotha, 11. Blackberry, 12. Fenugreek.

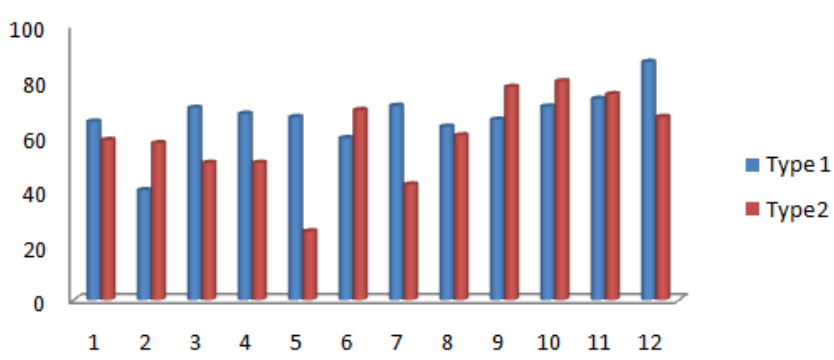

Figure 5 Graphical views of comparative study among the isolated phytomedicinal plants.

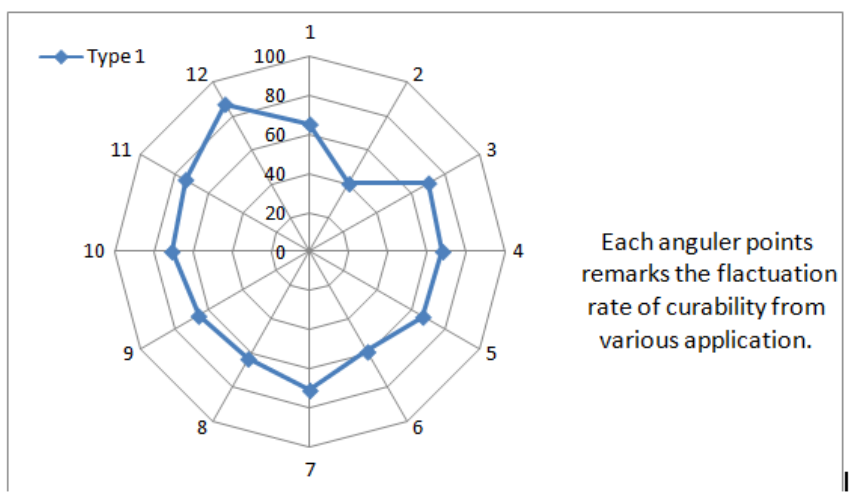

Figure 6 Fluctuation points are noted as curability percentages among isolated plants in Typel diabetes patients.

\section{Conclusion}

The phytomedicinal condition of different samples and their safety assessment revealed that most of the raw medicinal residues as a treatment were acceptable. The implemented safety of the samples depend not only the environmental conditions but also on the personal medication and doctors suggestion. Detailed study is required concerning more areas, increasing more sampling sites and their numbers for better growth of home yard medicinal plants. Storage duration of home yard phytomedicinal plants plays an important vital role and long storage duration favors more carcinogenic and chemical toxin degrading gradually their remedies potency. Therefore storage of processed raw medicine for long time should always be avoided and prohibited. As most of the plants constituents are able to produce toxins, it is necessary to monitor strictly medicinal products and then certify them for human consumption after performing a dose to patient.

\section{Acknowledgments}

None.

\section{Conflicts of interest}

The authors declare that there is no conflicts of interest.

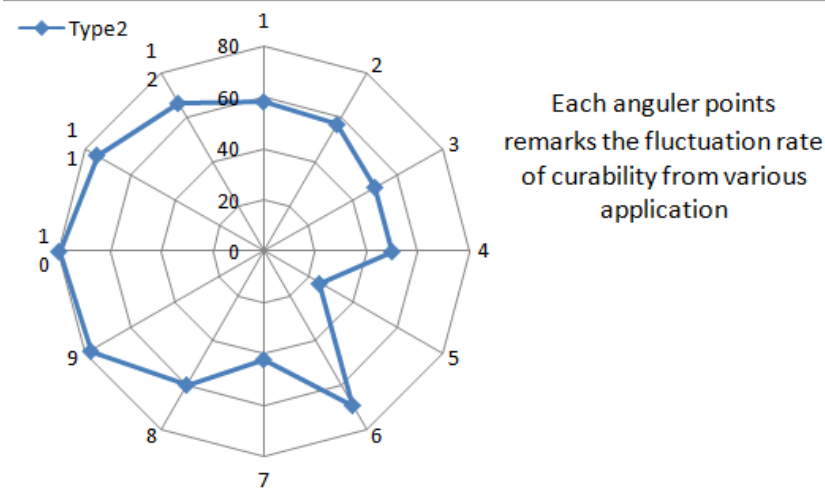

Figure 7 Fluctuation points are noted as curability percentages among isolated plants in Type 2 diabetes patients.

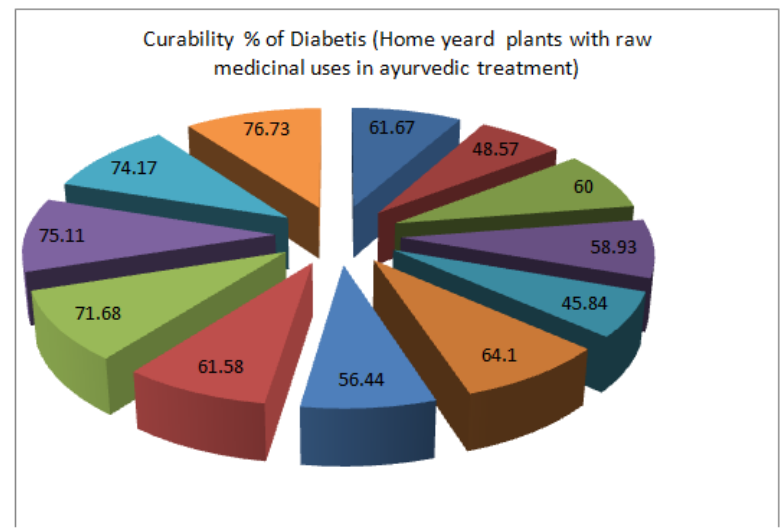

Figure 8 Curability percentages among isolated plants in Typel and Type 2 diabetes Patients.

\section{References}

1. Chinwanno W, Phawaphutanon N, Mahasarakam W, et al. Meditation in Tripitaka: Development of interpretation of meditation teaching in Theravada Buddhism in Thailand, (in Thai). Bangkok: Chulalongkorn University Press; 2000.

2. Phongsuphap S, Pongsupap Y. Analysis of heart rate variability during meditation by a pattern recognition method. Computing in Cardiology. 2011;38:197-200

3. Lou HC, Kjaer TW, Friberg L, et al. A 15 O-H 2 O PET study of meditation and the resting state of normal consciousness. Hum Brain Mapp. 1999;7(2):98-105.

4. Travis F, Pearson C. Pure consciousness: distinct phenomenological and physiological correlates of "consciousness itself". Int J Neurosci. 2000;100(1-4):77-89.

5. Newberg A, Alavi A, Baime M, et al. The measurement of regional cerebral blood flow during the complex cognitive task of meditation: A preliminary SPECT study. Psychiatr Res. 2001;106(2):113-122.

6. Gaylord C, Orme Johnson D, Travis F. The effects of the transcendental meditation technique and progressive muscle relaxation on EEG coherence, Stress reactivity and mental health in black adults, Int J Neurosci. 1989;46(1-2):77-86. 
7. Panjwani U, Gupta HL, Singh SH, et al. Effect of Sahaja yoga practice on stress management in patients of epilepsy. Indian J Physiol Pharmocol. 1995;39(2):111-116.

8. Lee MS, Bae BH, Ryu H, et al. Changes in alpha wave and state anxiety during Chun Do Sun Bup Qi-training in trainees with open eyes. Am J Chinese Med. 1997;25(3-4):289-299.

9. Badra LJ, Cooke WH, Hoag JB, et al. Respiratory modulation of human autonomic rhythms. Am J Physiol-Heart and Circulatory Physiol. 2001;280(6):H2674-H2688.

10. Dreifus LS, Agarwal JB, Botvinick EH, et al. Heart rate variability for risk stratification of life-threatening arrhythmias. J Am Coll Cardiol. 1993;22(3):948-950.

11. Heart rate variability: standards of measurement, physiological interpretation, and clinical use. Task Force of the European Society of Cardiology and the North American Society of Pacing and Electrophysiology. Circulation. 1996;93(5):1043-1065.

12. Kheder G, Kachouri A, Messouad MB, et al. Application of a nonlinear dynamic method in the analysis of the HRV (Heart rate variability) towards clinical application: Tiresome diagnosis. Proceedings of IEEE International Conference on Information and Communication Technologies. 2006. p. 177-182.

13. Vuksanovic V, Vera gal. Nonlinear and chaos characteristics of heart period time series: Healthy aging and postural change. Auton Neurosci. 2005;121(1-2):94-100.

14. Stein PK, Reddy A. Non-linear heart rate variability and risk stratification in cardiovascular disease. Indian Pacing and Electrophysiology Journal. 2005;5(3):210-220.

15. Brien I, Hare P, Corral R. Heart rate variability in healthy subjects: effect of age and the derivation of normal ranges for test of autonomic function. Br Heart J. 1986;55(4):348-354.

16. Al-Hazimi A, Al-Ama N, Syiamic A, et al. Time domain analysis of heart rate variability in diabetic patients with and without autonomic neuropathy. Annals of Saudi Medicine. 2002;22(5-6):400-402.

17. Kleiger RE, Stein PK, Bigger JT Jr. Heart rate variability: measurement and clinical utility. Ann Noninvasive Electrocardiol. 2005;10(1):88-101.

18. Seely AJ, Macklem PT. Complex systems and the technology of variability analysis. Crit Care. 2004;8(6):R367-R384.

19. Goshvarpour A, Goshvarpour A. Chaotic Behavior of Heart Rate Signals during Chi and Kundalini Meditation. I.J. Image, Graphics and Signal Processing. 2012;2:23-29.

20. Dey A, Mukherjee S, Palit SK, et al. A new kind of dynamical pattern towards distinction of pre-meditative and meditative states through HRV. International Journal of Research and Reviews in Computer Science 2012;3(3):1611-1615.

21. Goswami DP, Tibarewala DN, Bhattacharya DK. Analysis of heart rate variability signal in meditation using second-order difference plot. Journal of Applied Physics. 2011;109:114703.

22. Luciano Bernardi, Peter Sleight, Gabriele Bandinelli, et al. Effect of rosary prayer and yoga mantras on autonomic cardiovascular rhythms: comparative study. BMJ. 2001;323:22-29.
23. Hoshiyama M, A Hoshiyama A. Heart Rate Variability Associated with Experienced Zen Meditation. Computers in Cardiology. 2008;35:569-572.

24. Matzner SA. Heart rate variability during meditation. Statistical Signal Processing ECE. 2003;510:1-4.

25. Kiran Arora AK, Kaur D, Ghay R. Impact of meditation on autonomic nervous system- A research study. International Journal of Basic and Applied Medical Sciences. 2011;1(1):144-148.

26. Goswami DP, Tibarewala DN, Bhattacharya DK. Analysis of heart rate variability signal in meditations using second-order difference plot. Journal of Applied Physics. 2011;109(11):114703.

27. De Carvalho JLA, Rocha AF, Oliveira Nascimento FA, et al. Development of a Matlab software for analysis of heart rate variability. 6th International Conference on Signal Processing. 2002;2:1488-1491.

28. Goldberger AL, Luis Amaral AN, Leon Glass, et al. PhysioBank, PhysioToolkit and PhysioNet: components of a new research resource for complex physiologic signals. Circulation. 2000;101:e215-e220.

29. Piskorski J, Guzik P. Geometry of the Poincar'e plot of RR intervals and its asymmetry in healthy adults. Physiol Meas. 2007;28(3):287-300.

30. Malliani A, Pagani M, Furlan R, et al. Individual recognition by heart rate variability of two different autonomic profiles related to posture. Circulation. 1997;96(12):4143-4145.

31. Raetz SL, Richard CA, Garfinkel A, et al. Dynamic characteristics of cardiac R-R intervals during sleep and waking states. Sleep. 1991;14(6):526-533.

32. Schechtman VL, Raetz SL, Harper RK, et al. Dynamic analysis of cardiac R-R Intervals in normal infants and in infants who subsequently succumbed to the sudden infant death syndrome. Pediatric research. 1992;31(6):606-612.

33. Abásolo D, Hornero R, Gómez, et al. Analysis of EEG background activity in Alzheimer's disease patients with Lempel-Ziv complexity and central tendency measure. Medical Engineering and Physics. 2006;28(4):315-322.

34. Cohen ME, Hudson DL, Deedwania PC. Applying continuous chaotic modeling to cardiac signal analysis. IEEE Engineering in Medicine and Biology Magazine. 1996;15(5):97-102.

35. Kamath C. A new approach to detect congestive heart failure using Teager energy nonlinear scatter plot of RR interval series. Medical Engineering and Physics. 2012;34(7):841-848.

36. Thuraisingham RA. A Classification system to detect congestive heart failure using second-order difference plot of R-R intervals. Cardiology Research and Practice. 2009;807379:1-7.

37. Guzik P, Piskorski J, Krauze T, et al. Correlations between the Poincaré plot and conventional heart rate variability parameters assessed during paced breathing. J Physiol Sci. 2007;57(1):63-71. 